\title{
Weed Control in Beets ${ }^{1}$
}

\section{William M. Stall ${ }^{2}$}

Beets can be found as red beets, table beets or garden beets. Both the tops (greens) and the bottoms (swollen hypocotyle) may be eaten. Always check the label on beet greens because residue establishment varies.

Clopyralid (Stinger) has just received labeling for use postermergence, over-the-top of beets. At the present time however, Stinger may not be sold in Florida. This may change in the future, so check labeling in Florida. See Table 1.

1. This document is HS188, one of a series of the Horticultural Sciences Department, Florida Cooperative Extension Service, Institute of Food and Agricultural Sciences, University of Florida. Publication date: August 2003. Please visit the EDIS Website at http://edis.ifas.ufl.edu.

2. William M. Stall, professor, Horticultural Sciences Department, Cooperative Extension Service, Institute of Food and Agricultural Sciences, University of Florida, Gainesville, 32611

The use of trade names in this publication is solely for the purpose of providing specific information. It is not a guarantee or warranty of the product named, and does not signify that they are approved to the exclusion of others of suitable composition.

The Institute of Food and Agricultural Sciences is an equal opportunity/affirmative action employer authorized to provide research, educational information and other services only to individuals and institutions that function without regard to race, color, sex, age, handicap, or national origin. For information on obtaining other extension publications, contact your county Cooperative Extension Service office. Florida Cooperative Extension Service/Institute of Food and Agricultural Sciences/University of Florida/Christine Taylor Waddill, Dean. 
Table 1. Chemical weed controls: Beets.

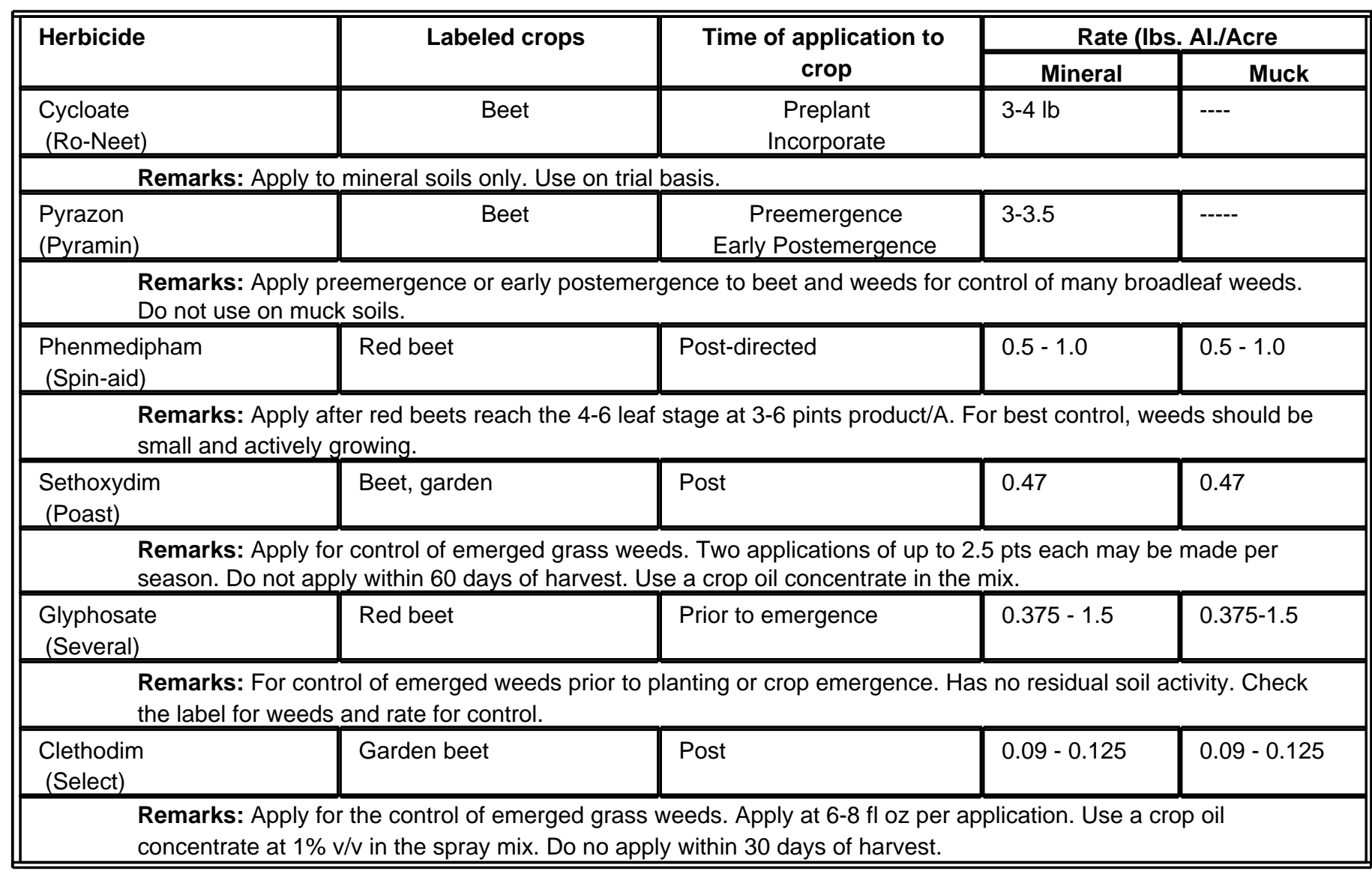

